\title{
Forest soil respiration reflects plant productivity across a temperature gradient in the Alps
}

\author{
Riccarda Caprez • Pascal A. Niklaus • \\ Christian Körner
}

Received: 14 October 2011/ Accepted: 10 May 2012/Published online: 10 June 2012

(C) Springer-Verlag 2012

\begin{abstract}
Soil respiration $\left(R_{\mathrm{S}}\right)$ plays a key role in any consideration of ecosystem carbon $(\mathrm{C})$ balance. Based on the well-known temperature response of respiration in plant tissue and microbes, $R_{\mathrm{s}}$ is often assumed to increase in a warmer climate. Yet, we assume that substrate availability (labile $\mathrm{C}$ input) is the dominant influence on $R_{\mathrm{s}}$ rather than temperature. We present an analysis of NPP components and concurrent $R_{\mathrm{s}}$ in temperate deciduous forests across an elevational gradient in Switzerland corresponding to a $6 \mathrm{~K}$ difference in mean annual temperature and a considerable difference in the length of the growing season (174 vs. 262 days). The sum of the short-lived NPP fractions ("canopy leaf litter," "understory litter," and "fine root litter") did not differ across this thermal gradient ( $+6 \%$ from cold to warm sites, n.s.), irrespective of the fact that estimated annual forest wood production was more than twice as high at low compared to high elevations (largely explained by the length of the growing season). Cumulative annual $R_{\mathrm{s}}$ did not differ significantly between elevations $\left(836 \pm 5 \mathrm{~g} \mathrm{C} \mathrm{m}^{-2} \mathrm{a}^{-1}\right.$ and $933 \pm 40 \mathrm{~g} \mathrm{C} \mathrm{m}^{-2}$ $\mathrm{a}^{-1}$ at cold and warm sites, $+12 \%$ ). Annual soil $\mathrm{CO}_{2}$ release thus largely reflected the input of labile $\mathrm{C}$ and not temperature, despite the fact that $R_{\mathrm{s}}$ showed the wellknown short-term temperature response within each site.
\end{abstract}

Communicated by Evan DeLucia.

R. Caprez $(\bowtie) \cdot$ C. Körner

Institute of Botany, University of Basel,

Schönbeinstrasse 6, 4056 Basel, Switzerland

e-mail: riccarda.caprez@unibas.ch

P. A. Niklaus

Institute of Evolutionary Biology and Environmental Studies,

University of Zürich, Winterthurerstrasse 190,

8057 Zürich, Switzerland
However, at any given temperature, $R_{\mathrm{s}}$ was lower at the warm sites (downregulation). These results caution against assuming strong positive effects of climatic warming on $R_{\mathrm{s}}$, but support a close substrate relatedness of $R_{\mathrm{s}}$.

Keywords Soil $\mathrm{CO}_{2}$ efflux $\cdot \mathrm{NPP} \cdot$ Elevation $\cdot$ Temperate forest - Acclimation - Temperature sensitivity

\section{Introduction}

Soil respiration $\left(R_{\mathrm{S}}\right)$, defined here as the the release of carbon dioxide $\left(\mathrm{CO}_{2}\right)$ from soils, is a major part of ecosystem respiration, and comprises (after photosynthesis) the second-largest terrestrial carbon (C) flux (IPCC 2001) at 75-100 $\mathrm{Pg} \mathrm{C} \mathrm{a}^{-1}$, more than 11-fold the current rate of fossil fuel combustion (Raich and Potter 1995). Since the atmosphere contains roughly $800 \mathrm{Pg} \mathrm{C}$, about $10 \%$ of the atmospheric $\mathrm{CO}_{2}$ is cycled through soils annually. Like any metabolic process, $R_{\mathrm{s}}$ is affected by the amount and quality of substrate and by soil environmental conditions such as temperature and moisture. Global mean air temperature is currently estimated to increase by $2-7^{\circ} \mathrm{C}$ by the end of this century (Allison et al. 2009). Using established temperature responses of respiration in plants, soils, and whole ecosystems, substantial increases in soil $\mathrm{C}$ release could be expected as a positive feedback to climate warming (Trumbore et al. 1996, Heath et al. 2005, Heimann and Reichstein 2008). The rationale for a warming-driven enhancement of net $\mathrm{C}$ losses by soils rests on the assumptions that (1) temperature is a relatively independent driver of $R_{\mathrm{s}}$, and (2) the sensitivity of $R_{\mathrm{s}}$ to warming will eventually cause $\mathrm{C}$ release to exceed $\mathrm{C}$ input to soils. Thus, several global biogeochemical models project soil $\mathrm{C}$ pools in terrestrial ecosystems to turn from a net $\mathrm{C}$ sink to a 
net C source by around mid-century (Cox et al. 2000, Cramer et al. 2001, Friedlingstein et al. 2006). This paper aims to challenge the view that instantaneous respiratory responses to temperature are scaling to a long-term, largearea signal.

$R_{\mathrm{S}}$ is commonly separated into an autotrophic part and a heterotrophic part. Autotrophic $R_{\mathrm{s}}$, i.e., respiration from live plant parts, includes root maintenance respiration, root growth respiration, and root nutrient uptake respiration, and is commonly assumed to contribute about half of the total soil $\mathrm{CO}_{2}$ release (e.g., Högberg et al. 2001). The heterotrophic part of $R_{\mathrm{s}}$ is related to respiratory losses by soil microbes (including mycorrhiza), which depend on the availability of organic substrate for microorganisms and the rate of decomposition of this substrate (Trumbore et al. 1990; Schulze et al. 2000). In the short term (hours to months), rates of soil organic $\mathrm{C}$ decomposition are highly temperature sensitive. However, in the longer term (decades to centuries), environmental factors such as temperature and water affect $\mathrm{CO}_{2}$ efflux only indirectly: through the rate of substrate production (Davidson and Janssens 2006, Kuzyakov and Gavrichkova 2010, Conant et al. 2011). An exception is water logging, where oxygen becomes a limiting factor (e.g., Davidson et al. 1998). Short-term substrate availability for decomposition depends on chemically and physically easily available organic compounds: plant and microbial residues and rhizodeposits of living roots. The concentrations of such substances are low (Fischer et al. 2007), and some of them have mean residence times of hours to days while others have mean residence times of a few months to a few years (litter). Hence, a sustained supply from above- and belowground litter and rhizodeposits is required to fuel these respiratory processes. Heterotrophic soil respiration can thus be assumed to strongly correlate with biomass production, as various studies have shown (Raich and Nadelhoffer 1989; Raich and Schlesinger 1992; Davidson et al. 2002b). For forests (in contrast to grassland), the heterotrophic respiratory fluxes can be divided into two parts: (1) fluxes associated with the recycling of biomass carbon $(\mathrm{C})$ that has accumulated over long periods, such as wood or humus $\mathrm{C}$, with natural lags in $\mathrm{CO}_{2}$ release of more than a hundred years, and (2) fractions of NPP associated with ongoing biomass recycling and fast turnover (aboveground litter production, root and mycorrhizal turnover, and recycling of $\mathrm{C}$ exported by roots to rhizosphere organisms).

Accordingly, experimental approaches such as the artificial heating of forest soils without concomitant heating of the canopy produce a step change in the temperature, inducing an initial but transient net loss of $\mathrm{C}$ to the atmosphere, with $R_{\mathrm{S}}$ returning to rates similar to those in unwarmed soils once the fraction of labile organic material has reached a new (lower) steady-state level (Luo et al.
2001; Strömgren and Linder 2002; Melillo et al. 2002; Knorr et al. 2005; Bradford et al. 2008). This transient response of respiratory soil $\mathrm{CO}_{2}$ release to step increases in soil temperature supports the notion that $R_{\mathrm{s}}$ is under strong substrate control in the long run. An initial but transient net loss of $\mathrm{C}$ to the atmosphere thus most likely overestimates the effect of long-term warming on $R_{\mathrm{S}}$. Respiratory metabolism, including soil respiration, responds to temperature instantaneously on an hourly or daily timescale, but we hypothesize that, on a full year to multi-year timescale, soil respiration is essentially a function of substrate availability (input of plant-derived organic $\mathrm{C}$ to soils), which in turn depends on temperature effects on productivity.

An NPP-based explanation of annual $R_{\mathrm{s}}$ assumes that labile $\mathrm{C}$ input sets the limit on soil $\mathrm{C}$ release from forests on a long-term (several years) basis, and thus contrasts with the concept of direct temperature-driven respiration. Natural climatic gradients based on either latitude or elevation offer conditions under which $\mathrm{C}$ dynamics reflect long-term whole-ecosystem adjustment to contrasting temperatures, and thus permit the exploration of ecological theory related to long-term temperature effects that are not biased by imposing a step change in temperature on soils only. Only a few studies, mainly performed in the Andes, have attempted to quantify and compare forest productivity and/or respiratory fluxes along elevational gradients (e.g., Leuschner et al. 2007; Girardin et al. 2010; Zimmermann et al. 2010); to our knowledge, no such study has been conducted in the temperate zone so far.

The present study takes advantage of a mean annual temperature increase of ca. $+6 \mathrm{~K}$ downslope of a $1200 \mathrm{~m}$ drop in elevation from the Central Swiss Alps to the Swiss Plateau. By restricting the comparison to alluvial sites with ample water supply, the gradient selected is not confounded by significant changes in the moisture regime. We present an analysis of the relation between NPP components in temperate deciduous forests and the concurrent soil $\mathrm{C}$ effluxes at two contrasting elevations along this thermal gradient. We hypothesize that the cumulative annual $R_{\mathrm{S}}$ values at contrasting temperatures reflect the difference in the production of nonrecalcitrant, short-lived biomass. An "experiment by nature," as we term it, can (1) be expected to reflect the combined effects of warming on all ecosystem processes, and (2) be expected to show signals that are well adjusted to the local temperature regime, given the rather slow rates of climatic warming (currently ca. $0.13 \mathrm{~K}$ per decade; IPCC 2007), thus contrasting with short-term soilonly warming trials (step changes) in forests that are otherwise exposed to the contemporary climate.

In the present study, "steady state" refers to a forest state in which annual leaf litter fall has reached a near-toconstant value (maximum LAI), and in which fine roots 
have explored the available soil space so that the fine root biomass does not increase further (near-to-constant fine root turnover). At the same time, stems, branches, and coarse roots keep accumulating biomass, and the forest grows in height, so "steady state" refers to the flow of NPP fractions that are quickly turning over, including aboveground litter, root and mycorrhizal turnover, and root exudates.

\section{Methods}

Study site and experimental design

A field experiment was set up in early spring 2009, which consisted of two deciduous forest stands in the Central Swiss Alps at ca. $1500 \mathrm{~m}$ a.s.l., referred to as "cold" or "high-elevation" sites, and two low-elevation deciduous forest stands in the foothills of the Swiss Plateau at ca. $300 \mathrm{~m}$ a.s.l., referred to as "warm" or "low-elevation" sites (Table 1). The elevational cline spanned by these core sites $(1200 \mathrm{~m})$ corresponds to a difference in mean annual temperature of about $6 \mathrm{~K}$. Each site comprised an area of $50 \mathrm{~m} \times 50 \mathrm{~m}$, surrounded by a buffer zone at least $10 \mathrm{~m}$ in width. The cold high-elevation sites were homogeneous closed-canopy stands of Salix fragilis L., which originate from natural regeneration and had a mean age of ca. 40 years. The warm low-elevation sites were closed-canopy stands dominated by Acer pseudoplatanus L. (with a few Quercus rubra L. individuals at one site), afforested about 40-60 years ago. Air temperature (at $2 \mathrm{~m}$ above the ground) and soil temperature (at $10 \mathrm{~cm}$ depth) were recorded throughout the field study on an hourly basis at each site (HOBO TidbiT v2, Onset Computer Corp., Bourne, MA, USA). The length of the thermal growing season was defined here as the number of days with a daily mean air temperature above $5{ }^{\circ} \mathrm{C}$. At each site, hourly averages of soil moisture and precipitation were recorded below the canopy (EM50 data loggers connected to a ECRN-100 rain gauge and four 10HS soil moisture probes installed at $10 \mathrm{~cm}$ depth; Decagon Devices, Pullman, WA, USA).

\section{Forest stand characteristics}

We estimated stem basal area $\left(B A\right.$, in $\left.\mathrm{m}^{2}\right)$ by measuring stem circumference at breast height $(1.3 \mathrm{~m}$ above the ground) in three plots of size $10 \mathrm{~m} \times 10 \mathrm{~m}$ per site in early spring in three subsequent years for all trees with a diameter exceeding $10 \mathrm{~cm}$ (very few trees were $<10 \mathrm{~cm}$ in diameter). This resulted in $70 \pm 8$ trees and $37 \pm 8$ trees within the three plots at the cold and warm sites, respectively. Forest stand height $(H$, in $\mathrm{m})$ was estimated as the height of five randomly selected trees per plot using an optical reading clinometer (PM-5, Suunto, Espoo, Finland). Because species-specific allocation rules for stem and branch biomass were not available, we estimated woody biomass of all tree species assuming a near-cylindrical

Table 1 Location, climatic, and stand characteristics of the two study sites at high elevation (cold sites) and the two study sites at low elevation (warm sites)

\begin{tabular}{|c|c|c|c|c|}
\hline \multirow{2}{*}{$\overline{\text { Location }}$} & \multicolumn{2}{|c|}{ High-elevation sites } & \multicolumn{2}{|l|}{ Low-elevation sites } \\
\hline & $46^{\circ} 36^{\prime} 16^{\prime \prime} \mathrm{N}$ & $46^{\circ} 36^{\prime} 21^{\prime \prime} \mathrm{N}$ & $47^{\circ} 32^{\prime} 37^{\prime \prime} \mathrm{N}$ & $47^{\circ} 32^{\prime} 53^{\prime \prime} \mathrm{N}$ \\
\hline & $8^{\circ} 31^{\prime} 01^{\prime \prime} \mathrm{E}$ & $8^{\circ} 31^{\prime} 21^{\prime \prime} \mathrm{E}$ & $7^{\circ} 46^{\prime} 22^{\prime \prime} \mathrm{E}$ & $8^{\circ} 13^{\prime} 34^{\prime \prime} \mathrm{E}$ \\
\hline Elevation (m a.s.1.) & 1515 & 1508 & 296 & 330 \\
\hline Dominant species & Salix fragilis & Salix fragilis & Acer platanoides & Acer platanoides \\
\hline Stand age (years) & ca. 40 & ca. 40 & $50-60$ & $40-50$ \\
\hline$T_{\text {air }}$ full year $\left({ }^{\circ} \mathrm{C}\right)$ & $3.8(-23.6,28.4)$ & $3.6(-25.7,27.5)$ & $10.6(-15.4,32.0)$ & $10.4(-14.0,29.4)$ \\
\hline$T_{\text {air }}$ growing season $\left({ }^{\circ} \mathrm{C}\right)$ & $10.4(5.0,17.3)$ & $10.7(5.1,16.9)$ & $14.3(5.1,24.5)$ & $14.5(5.2,23.3)$ \\
\hline$T_{\text {soil }}\left({ }^{\circ} \mathrm{C}\right)$ & $5.3(0.0,15.6)$ & $5.5(0.1,14.7)$ & $10.5(0.6,21.0)$ & $10.3(1.6,19.4)$ \\
\hline Soil moisture (vol \%) & $29.8(19.1,39.8)$ & $31.3(19.9,41.0)$ & $36.6(24.3,47.7)$ & $40.1(29.4,47.4)$ \\
\hline Precipitation $\left(\mathrm{mm} \mathrm{y}^{-1}\right)$ & 734 & 752 & 813 & 853 \\
\hline Stem basal area $\left(\mathrm{m}^{2} \mathrm{ha}^{-1}\right)$ & $37.9 \pm 2.1$ & $38.9 \pm 3.2$ & $54.9 \pm 4.2$ & $41.6 \pm 1.9$ \\
\hline Canopy height (m) & $7.8 \pm 0.5$ & $6.6 \pm 0.1$ & $21.1 \pm 0.1$ & $20.5 \pm 0.3$ \\
\hline Stem and brench wood biomass $\left(\mathrm{t} \mathrm{C} \mathrm{ha-}{ }^{-1}\right)$ & $54 \pm 3$ & $50 \pm 5$ & $293 \pm 24$ & $128 \pm 17$ \\
\hline LAI $\left(\mathrm{m}^{2} \mathrm{~m}^{-2}\right)$ & $3.7 \pm 0.2$ & $4.1 \pm 0.1$ & $5.5 \pm 0.1$ & $5.0 \pm 0.2$ \\
\hline Annual wood increment ( $\left.\mathrm{t} \mathrm{C} \mathrm{ha} \mathrm{h}^{-1} \mathrm{a}^{-1}\right)$ & $2.29 \pm 0.03$ & $1.89 \pm 0.03$ & $5.01 \pm 0.20$ & $4.80 \pm 0.34$ \\
\hline
\end{tabular}

Temperature and soil moisture are given as annual (or seasonal) means, with the minima and maxima (in parentheses) measured on an hourly basis. Precipitation was measured below the canopy of the forest stands. Basal area, canopy height, woody biomass, and LAI were recorded at the beginning of the field study (April 2009); the within-site mean \pm SE is presented here 
shape for the combined stem and branch xylem (sapwood area), which was estimated by stem basal area and canopy height:

$W_{\mathrm{C}}=(B A \times H) \times \rho \times 0.5$,

where $W_{\mathrm{C}}$ (in $\mathrm{kg}$ ) is the aboveground woody biomass $\mathrm{C}$ per ground area, $\rho$ stands for wood density (Salix: $362 \mathrm{~kg} \mathrm{~m}^{-3}$; Acer: $522 \mathrm{~kg} \mathrm{~m}^{-3}$; compiled by Perruchoud et al. 1999), and dry stem biomass is assumed to contain $50 \% \mathrm{C}$ per unit weight.

The leaf area index (LAI) was estimated using a ceptometer (AccuPAR LP-80, Decagon Devices Inc.). The reference measurements were taken immediately after the forest measurement in an open area within a distance of $50 \mathrm{~m}$ under clear sky conditions. All measurements were accomplished in mid-August, when canopy foliage reached its maximum. Specific leaf area (SLA) of the litter was estimated on freshly fallen leaves that were randomly collected from the litter traps (see next section) at the end of September. Leaf area was measured using a LI-3100 area meter (LI-COR Inc., Lincoln, NE, USA) and the biomass of the same leaves was determined after drying at $80{ }^{\circ} \mathrm{C}$.

\section{Forest litter production}

Forest NPP comprises "long-lived" components that contribute to $\mathrm{C}$ recycling when trees die or become harvested, such as wood and coarse-root growth, and "short-lived" components that feed more directly into respiratory belowground signals. These short-lived NPP components comprise above- and belowground litter as well as nontissue components: root exudates and $\mathrm{C}$ export to mycorrhizae. In the present study, we adopted the selected shortlived NPP proxies "canopy leaf litter fall," "understory biomass," and "fine root production" in ingrowth cores (our proxy for belowground NPP). The sum of these shortlived NPP proxies is termed the "total litter production."

To estimate canopy leaf litter production, six plastic litter traps $\left(0.25 \mathrm{~m}^{2}\right.$ ground area $)$ with porous ground (sieve bottom) were installed at random locations within each study site in early autumn in two subsequent years, shortly before the leaves began to fall. The litter traps were emptied regularly, and the accumulated litterfall was dried at $80{ }^{\circ} \mathrm{C}$. C content, quantified in a dry combustion elemental analyzer (Elementar Vario EL III, Hanau, Germany), ranged from $49 \%$ to $54 \%$ of dry mass at all sites. Understory vegetation biomass was determined by harvest at peak biomass at ground level in two areas of size $1 \mathrm{~m}^{2}$ each per study site. At the beginning of the growing season, a total of 40 soil cores per study site $(3.5 \mathrm{~cm}$ diameter $\times 12 \mathrm{~cm}$ depth) were collected. The soil cores were kept frozen until the extraction of fine and coarse roots, which were then dried at $80{ }^{\circ} \mathrm{C}$. The holes created by root sampling were replaced by mesh cylinders (PET filament, $2 \mathrm{~mm}$ mesh size) and filled with sieved root-free soil taken in close proximity to the respective study site. Soil in these ingrowth cores was compacted to a similar bulk density to that found on the site. We found substantial root ingrowth after one year, and thus harvested the complete set of ingrowth cores. As a proxy of fine root turnover, we calculated the ratio of annual fine root ingrowth (NPP) to the mean fine root standing crop (Aber et al. 1985).

\section{Soil respiration}

Soil respiration $\left(R_{\mathrm{S}}\right)$ was measured using a portable custom-made static chamber system equipped with an openpath infrared gas analyzer and relative humidity/temperature sensors (GMP343 carbon dioxide probe, HMP75 rH/T probe; Vaisala, Vantaa, Finland; described in Bader and Körner 2010). This design avoids any pumps, thus preventing known problems with flow-through chambers, where minute pressure variations can alter the $\mathrm{CO}_{2}$ flow across the delicate soil-air interface (Lund et al. 1999). Twelve polypropylene collars $(20 \mathrm{~cm}$ diameter $\times 7 \mathrm{~cm}$ height) were installed at randomly selected positions within each study site. The collars were inserted to a depth of $3 \mathrm{~cm}$ into the ground 2-3 weeks prior to the first measurement. These collars permitted leakproof attachment of the soil respiration chamber, allowing the repeated measurement of the same soil area over time. The collars remained at the same location throughout the entire study. $R_{\mathrm{S}}$ was recorded biweekly throughout the growing season. From late autumn to early spring, $R_{\mathrm{s}}$ was recorded once a month at the low-elevation sites. Winter measurements at the high-elevation sites were restricted by heavy snowpack. For wintertime $R_{\mathrm{s}}$ measurement at the cold sites, snow was gently removed to reach the buried collars. Soils remained unfrozen under snow. After several attempts throughout the winter months, one reliable measurement was achieved in March 2010, when ambient air temperatures were sufficiently high for the soil surface not to freeze after excavating the collars. During these measurements, gas fluxes reached a steady state after an initial degassing period, i.e., $R_{\mathrm{S}}$ rates remained steady without a significant decrease for $0.5-2.5 \mathrm{~h}$ after snow removal. Soil respiration rates were calculated by linear regression of recorded headspace $\mathrm{CO}_{2}$ concentrations against time (48 automatic readings over a period of $4 \mathrm{~min}$, starting $1 \mathrm{~min}$ after the placement of the chamber on the collar). The data recorded during the first minute after the installation of the chamber were not used to avoid flux disturbances following chamber placement (Davidson et al. 2002a). Simultaneously with the $R_{\mathrm{s}}$ measurements, soil temperature and soil moisture at the chamber site were recorded manually (soil temperature: 
GTH 175/Pt digital thermometer, Greisinger Electronic, Germany; soil moisture: ThetaProbe soil moisture sensor ML2x, Delta-T Devices Ltd., Cambridge, UK), thus complementing the data collected by the automatic data logger.

In order to ensure that results did not reflect the bychance presence of certain tree taxa at the selected study sites, we measured $R_{\mathrm{s}}$ simultaneously at the core sites and at supplementary sites with different tree taxa in summer 2010. The supplementary sites at high elevation (cold sites) were one forest stand of Sorbus aucuparia L. $\left(46^{\circ} 36^{\prime} 48^{\prime \prime} \mathrm{N}\right.$, $8^{\circ} 34^{\prime} 08^{\prime \prime} \mathrm{E} ; 1635 \mathrm{~m}$ a.s.1.) and one forest stand of Betula pubescens $\left(46^{\circ} 42^{\prime} 53^{\prime \prime} \mathrm{N}, 8^{\circ} 54^{\prime} 56^{\prime \prime} \mathrm{E} ; 1325 \mathrm{~m}\right.$ a.s.1.). At low elevation (warm sites), we chose five supplementary sites of mixed forest dominated by Fagus sylvatica L. $\left(47^{\circ} 32^{\prime} 39^{\prime \prime} \mathrm{N}, 7^{\circ} 45^{\prime} 42^{\prime \prime} \mathrm{E} ; 4^{\circ} 32^{\prime} 40^{\prime} \mathrm{N}, 8^{\circ} 13^{\prime} 21^{\prime \prime} \mathrm{E}\right.$; $47^{\circ} 07^{\prime} 05^{\prime \prime} \mathrm{N}, 8^{\circ} 18^{\prime} 42^{\prime \prime} \mathrm{E} ; 4^{\circ} 31^{\prime} 44^{\prime \prime} \mathrm{N}, 7^{\circ} 47^{\prime} 22^{\prime \prime} \mathrm{E}$; $47^{\circ} 22^{\prime} 16^{\prime \prime} \mathrm{N}, 8^{\circ} 11^{\prime} 13^{\prime \prime} \mathrm{E}$; all between 300 and $500 \mathrm{~m}$ a.s.1.). Daytime $R_{\mathrm{s}}$ was recorded on four occasions at the core sites and the supplementary sites (high elevation: $n=4$; low elevation: $n=7$ ) in mid-season (July and August) 2010.

\section{Soil physicochemical analysis}

Two soil pits were dug per study site and the excavated profile was sampled at depths of 5, 10, 20, 30, 40, and $50 \mathrm{~cm}$ using a $35 \mathrm{~mm}$ diameter $\times 50 \mathrm{~mm}$ length auger. The profiles included the organic topsoil layer, humic layers, and mineral layers. The soil samples were sieved ( $2 \mathrm{~mm}$ ) and oven-dried at $105{ }^{\circ} \mathrm{C}$ to determine the fine earth density. Subsamples of each soil core were oven dried at $105{ }^{\circ} \mathrm{C}$ and ground to powder to quantify the total $\mathrm{C}$ and $\mathrm{N}$ concentrations in an elemental analyzer (ThermoFinnigan FlashEA 1112, Milan, Italy) after carbonates were removed from soils by acid fumigation (Harris et al. 2001). Soil $\mathrm{pH}$ was measured in $0.1 \mathrm{M} \mathrm{KCl}$ solution.

Data analysis

$R_{\mathrm{S}}$ rates ( $\mu \mathrm{mol} \mathrm{CO}_{2} \mathrm{~m}^{-2} \mathrm{~s}^{-1}$ ) were related to soil temperature $(T, 10 \mathrm{~cm}$ depth) by fitting a nonlinear least squares model after Lloyd and Taylor (1994), which expresses $R_{\mathrm{s}}$ in terms of the respiration rate at $10{ }^{\circ} \mathrm{C}\left(R_{\mathrm{s} 10}\right)$ and a parameter $E_{0}$ that models temperature sensitivity:

$R_{\mathrm{S}}=R_{\mathrm{s} 10} e^{E_{0}\left(\frac{1}{56.02}-\frac{1}{T-227.13}\right)}$.

Annual soil $\mathrm{CO}_{2}$ efflux was estimated at each core site by predicting $R_{\mathrm{s}}$ at hourly intervals, based on the automatically logged soil temperature. The temperature sensitivity expressed by $Q_{10}$ values within elevation were then estimated by comparing $R_{\mathrm{s}}$ rates when the temperature was increased from $5{ }^{\circ} \mathrm{C}$ to $15^{\circ} \mathrm{C}$ :
$Q_{10}=\left(\frac{R_{\mathrm{s} 2}}{R_{\mathrm{s} 1}}\right)^{\left(\frac{10^{\circ} \mathrm{C}}{T_{2}-T_{1}}\right)}$,

where $R_{\mathrm{s} 2}$ and $R_{\mathrm{s} 1}$ are the $R_{\mathrm{s}}$ rates at the higher $\left(T_{2}=15\right.$ $\left.{ }^{\circ} \mathrm{C}\right)$ and lower $\left(T_{1}=5{ }^{\circ} \mathrm{C}\right)$ soil temperatures, respectively. In order to estimate $Q_{10}$ across elevations, annual $R_{\mathrm{s}}$ rates at the contrasting temperatures (elevations) were compared using Eq. 2.

Effects of elevation (temperature) on NPP components or the sum of NPP components, annual $R_{\mathrm{s}}$, and pools of soil $\mathrm{C}$ and $\mathrm{N}$ were tested using a one-way analysis of variance. Normality and homoscedasticity were examined visually using diagnostic plots, and non-normally distributed rates were log-transformed (canopy leaf litter, soil $\mathrm{C}$ and $\mathrm{N}$ contents) or power-transformed $\left(x^{-0.4}\right.$; NPP fine roots). Error estimates in the text and figures are standard errors of site means, and effects were considered significant at $P<0.05$. Due to the low replication and therefore statistical power, effects with $P$ values $<0.1$ were considered marginally significant. All statistical analyses were carried out using R (R Development Core Team 2009; http://www. r-project.org).

\section{Results}

Climatic conditions

There was substantial seasonal variation in topsoil temperature and moderate changes in topsoil water content and precipitation at both the cold high-elevation and the warm low-elevation sites during the study years. Differences between sites at each elevation were almost negligible (Fig. 1c-f). The growing season (daily mean air temperature $>5{ }^{\circ} \mathrm{C}$ ) accounted for $174 \pm 2$ days at the cold sites, and lasted $262 \pm 4$ at the warm sites; i.e., there was a shortening of the growing season by nearly three months with elevation. Sites at high elevation were snow-covered (to a max. of $1 \mathrm{~m}$ depth) from the beginning of December to mid April, whereas at low elevation the forest floor was only periodically covered with a few centimeters of snow, mainly between early December and late February. Mean annual air temperatures during the experimental period were $3.7 \pm 0.1{ }^{\circ} \mathrm{C}$ and $10.5 \pm 0.1{ }^{\circ} \mathrm{C}$ at the cold and warm sites, respectively (Table 1 ), implying a mean air temperature difference of 6-7 K for the $1200 \mathrm{~m}$ difference in elevation. Soil volumetric water content (VWC) was permanently higher at the warm sites, but in general all soils were moist throughout the study period (Table 1; Fig. 1e, f). By comparing tree stands on alluvial plains at both high and low elevations, we have avoided differences in the most common confounding site variable, soil moisture. 
Fig. 1 Seasonal variations in a, b $R_{\mathrm{S}}($ mean $\pm \mathrm{SE}, n=12)$, c, d soil temperature in the top $10 \mathrm{~cm}, \mathbf{e}, \mathbf{f}$ volumetric water content (VWC) in the top $10 \mathrm{~cm}$ and below-canopy precipitation, recorded at the individual study sites at high elevation (cold sites) and low elevation (warm sites) from April 2009 to March 2010 (full year). Circles and solid lines denote data from one study site, while triangles and dashed lines denote data from the other study site at the corresponding elevation. The gray-shaded area indicates the period when the soil was covered with snow

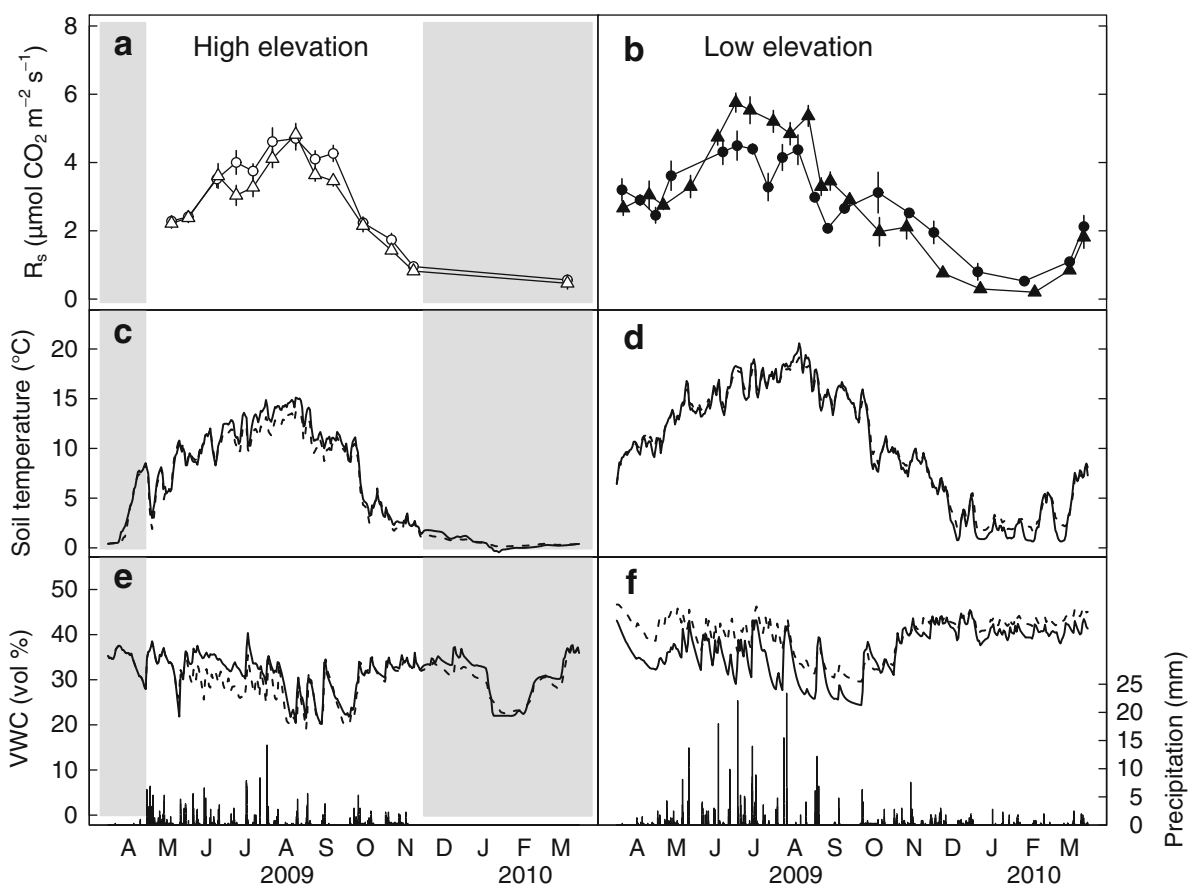

\section{Forest stand characteristics}

Stem basal area did not differ significantly between elevations, whereas tree height increased from the cold to the warm sites $(P=0.002)$, resulting in lower aboveground woody biomass at the cold high-elevation sites compared to the warm low-elevation sites, though this effect is marginally significant only due to a large variance in woody biomass at the warm sites $(P=0.09$; Table 1$)$. Similar to woody biomass, annual wood increment was higher at the warm compared to the cold sites $(+140 \%$; $P=0.03$; Table 1). However, accounting for the length of the growing season, wood increment was only $60 \%$ higher at the warm low-elevation than at the cold high-elevation sites. Canopy LAI at peak season was also slightly higher at the warm sites $(P=0.06$; Table 1$)$, whereas SLA was similar at both elevations $\left(160-180 \mathrm{~cm}^{2} \mathrm{~g}^{-1}\right)$.

\section{Forest litter production}

Canopy leaf litter production was $117 \pm 22 \mathrm{~g} \mathrm{C} \mathrm{m}^{-2} \mathrm{a}^{-1}$ at the cold and $235 \pm 27 \mathrm{~g} \mathrm{C} \mathrm{m}^{-2} \mathrm{a}^{-1}$ at the warm sites $(P=0.09$; Table 2$)$, but this marginally significant difference almost disappeared when divided by the number of days of the growing season (Table 3). Production of understory vegetation (herbaceous species) was $128 \pm 28 \mathrm{~g}$ $\mathrm{C} \mathrm{m}^{-2} \mathrm{a}^{-1}$ at the cold sites and $101 \pm 44 \mathrm{~g} \mathrm{C} \mathrm{m}^{-2} \mathrm{a}^{-1}$ at the warm sites (Table 2). When expressed per day of the growing season, this trend was amplified but remained nonsignificant (Table 3). In contrast to the aboveground trends in NPP, annual fine root ingrowth decreased
Table 2 Annual NPP (in $\mathrm{g} \mathrm{C} \mathrm{m}^{-2} \mathrm{a}^{-1}$ ) of short-lived components, annual $R_{\mathrm{s}}$, and the percentage changes in each of these annual $\mathrm{C}$ fluxes upon moving from cold high-elevational sites to warm lowelevational sites

\begin{tabular}{lcclc}
\hline & $\begin{array}{l}\text { High } \\
\text { elevation }\end{array}$ & $\begin{array}{l}\text { Low } \\
\text { elevation }\end{array}$ & $\begin{array}{l}\text { In/decrease } \\
(\%)\end{array}$ & $P$ \\
\hline Canopy litter & $117 \pm 22$ & $235 \pm 27$ & +101 & $(*)$ \\
Understory & $128 \pm 28$ & $101 \pm 44$ & -21 & n.s. \\
$\quad$ vegetation & & & & \\
Fine root ingrowth & $97 \pm 14$ & $28 \pm 4$ & -71 & $*$ \\
Total litter & $\mathbf{3 4 3} \pm \mathbf{2 1}$ & $\mathbf{3 6 5} \pm \mathbf{1 3}$ & $\mathbf{+ 6}$ & n.s. \\
$\begin{array}{l}\text { Annual } \boldsymbol{R}_{\boldsymbol{s}} \\
\quad\left(\mathbf{g ~ C ~} \mathbf{~ m}^{-\mathbf{2}} \mathbf{a}^{-\mathbf{1}}\right)\end{array}$ & $\mathbf{8 3 6} \pm \mathbf{5}$ & $\mathbf{9 3 3} \pm \mathbf{4 0}$ & $\mathbf{+ 1 2}$ & n.s. \\
\hline
\end{tabular}

Total litter refers to the sum of the canopy litter, understory litter, and fine root ingrowth. The mean $\pm \mathrm{SE}$ is presented here

(*) $0.05<P<0.1$; $P<0.05$; ** $P<0.01$

considerably from $97 \pm 14 \mathrm{~g} \mathrm{C} \mathrm{m}^{-2} \mathrm{a}^{-1}$ at the cold to $28 \pm 4 \mathrm{~g} \mathrm{C} \mathrm{m}^{-2} \mathrm{a}^{-1}$ at the warm sites $(P=0.03$; Table 2$)$, and the effect became even stronger when expressed per day of the growing season (Table 3). Similarly, fine root biomass at the beginning of the field study declined from the cold to the warm sites $\left(46 \pm 1 \mathrm{~g} \mathrm{C} \mathrm{m}^{-2} \mathrm{a}^{-1}\right.$ vs. $19 \pm 2 \mathrm{~g} \mathrm{C} \mathrm{m}^{-2}$ $\mathrm{a}^{-1} ; P=0.009$ ). Both mean fine root turnover (cold sites: $0.37 \pm 0.03 \mathrm{a}^{-1}$; warm sites: $0.31 \pm 0.02 \mathrm{a}^{-1}$ ) and mean root duration (cold sites: $2.7 \pm 0.2$ years; warm sites: $3.3 \pm 0.2$ years) were similar at the contrasting temperature regimes. Because of the shorter season, the "functional duration" (number of days of high metabolic activity) is thus reduced at the cold sites. 
Table 3 Productivity of short-lived components expressed per day of growing season (i.e., mean daily NPP during the growing season in $\mathrm{g} \mathrm{C} \mathrm{m}^{-2} \mathrm{~d}^{-1}$; the number of days experiencing a $24 \mathrm{~h}$ temperature mean above $5{ }^{\circ} \mathrm{C}$ : high elevation $174 \pm 2$ days, low elevation $262 \pm 4$ days) and the percentage change on moving from the cold high-elevation sites to the warm low-elevation sites. The mean $\pm \mathrm{SE}$ is presented here

\begin{tabular}{lllll}
\hline & $\begin{array}{l}\text { High } \\
\text { elevation }\end{array}$ & $\begin{array}{l}\text { Low } \\
\text { elevation }\end{array}$ & $\begin{array}{l}\text { In/decrease } \\
(\%)\end{array}$ & $P$ \\
\hline Canopy litter & $0.66 \pm 0.13$ & $0.90 \pm 0.09$ & +35 & n.s. \\
Understory litter & $0.74 \pm 0.16$ & $0.39 \pm 0.17$ & -48 & n.s. \\
Fine root ingrowth & $0.56 \pm 0.08$ & $0.11 \pm 0.01$ & -81 & $* *$ \\
\hline
\end{tabular}

(*) $0.05<P<0.1$; $P<0.05$; ** $P<0.01$

\section{Soil respiration}

$R_{\mathrm{S}}$ rates measured throughout the sampling year at the four core sites showed pronounced seasonality (Fig. 1a, b), with rates $<1 \mu \mathrm{mol} \mathrm{CO}_{2} \mathrm{~m}^{-2} \mathrm{~s}^{-1}$ in February and March at both the cold high-elevation and the warm low-elevation sites, and peak rates of $4.8 \mu \mathrm{mol} \mathrm{CO} \mathrm{Cm}_{2}^{-2} \mathrm{~s}^{-1}$ at the cold sites in August and $5.8 \mu \mathrm{mol} \mathrm{CO} \mathrm{CO}^{-2} \mathrm{~s}^{-1}$ at the warm sites in July. As soon as air and soil temperatures exceeded $4{ }^{\circ} \mathrm{C}$ in spring, $R_{\mathrm{S}}$ started to rise. At the cold sites, this occurred in mid-May following snowmelt, while this threshold was passed at the warm sites at the end of March. At the cold sites, $R_{\mathrm{s}}$ declined continuously during October to its lowest winter values, whereas $R_{\mathrm{S}}$ dropped more rapidly in September at the warm sites, with the temperature reducing from about $20^{\circ} \mathrm{C}$ to $15^{\circ} \mathrm{C}$ during a period of reduced rainfall (soil moisture: $26 \%$ to $29 \%$; Fig. 1f). While $R_{\mathrm{S}}$ values at the two cold high-elevation sites ran parallel throughout the year, $R_{\mathrm{S}}$ values at the two warm low-elevation sites diverged during July and August, achieving the maximum $R_{\mathrm{S}}$ discrepancy of about $2 \mu \mathrm{mol}$ $\mathrm{CO}_{2} \mathrm{~m}^{-2} \mathrm{~s}^{-1}$ (Fig. 1a, b). On an annual basis (365 days), the average daytime $R_{\mathrm{s}}$ was $2.9 \pm 0.1 \mu \mathrm{mol} \mathrm{CO} \mathrm{CO}_{2} \mathrm{~m}^{-2} \mathrm{~s}^{-1}$ for the cold sites and $2.8 \pm 0.2 \mu \mathrm{mol} \mathrm{CO} \mathrm{C} \mathrm{m}^{-2} \mathrm{~s}^{-1}$ for the warm sites, so it did not vary significantly across the $6 \mathrm{~K}$ elevational cline in temperature.

$R_{\mathrm{S}}$ at the cold sites in mid March was $0.5 \pm 0.1 \mu \mathrm{mol}$ $\mathrm{CO}_{2} \mathrm{~m}^{-2} \mathrm{~s}^{-1}$ at a topsoil temperature of $0.3{ }^{\circ} \mathrm{C}$. For the annual soil $\mathrm{CO}_{2}$ efflux, this rate is assumed to represent winter rates at the cold sites from mid-December 2009 to mid-April (the soil temperature barely changed under snow cover during that period). Had actual rates been lower (e.g., $0.1 \mu \mathrm{mol} \mathrm{CO}_{2} \mathrm{~m}^{-2} \mathrm{~s}^{-1}$ ), the elevational effect on the annual $\mathrm{CO}_{2}$ efflux calculated by Eq. 2 would not have been significantly affected.

Soil temperature accounted for $70-80 \%$ of the seasonal variation in $R_{\mathrm{s}}$, and $Q_{10}$ within elevation was similar at the two elevations (cold sites: $R^{2}=0.79, \quad P<0.001$, $Q_{10}=2.1 \pm 0.3 ; \quad$ warm sites: $R^{2}=0.70, \quad P<0.001$,

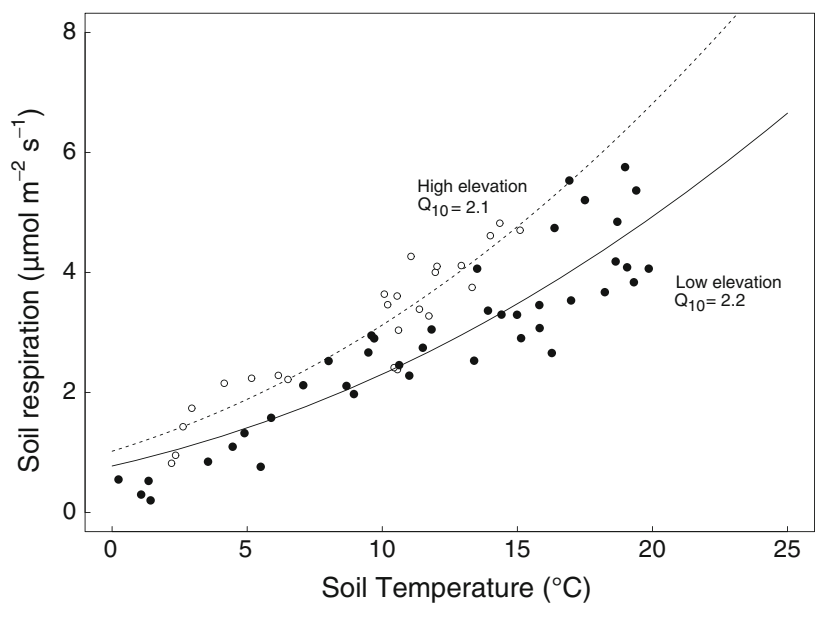

Fig. 2 Seasonal response of $R_{\mathrm{s}}$ to soil temperature (10 $\mathrm{cm}$ depth) at the cold high-elevational sites (open symbols, dashed line) and at the warm low-elevation (filled symbols, solid line), fitted with Lloyd and Taylor (1994) functions. Data points are campaign averages of the $R_{\mathrm{s}}$ rates at each study site $(n=12)$ throughout the sampling year. $Q_{10}$ values are estimated by comparing the $R_{\mathrm{s}}$ rates obtained upon increasing the temperature from $5{ }^{\circ} \mathrm{C}$ to $15^{\circ} \mathrm{C}$

$Q_{10}=2.2 \pm 0.6$; Fig. 2). Comparing annual $R_{\mathrm{s}}$ across elevation (a temperature rise of $6 \mathrm{~K}$ ) resulted in a $Q_{10}$ of $1.2 \pm 0.1$.

Total annual respired $\mathrm{C}$ amounts, obtained by modellng hourly values of $R_{\mathrm{S}}$ rates using Eq. 2, were only $12 \%$ (n.s.) higher at the warm sites relative to the cold sites $(836 \pm 5 \mathrm{~g}$ $\mathrm{C} \mathrm{m}^{-2} \mathrm{a}^{-1}$ vs. $933 \pm 40 \mathrm{~g} \mathrm{C} \mathrm{m}^{-2} \mathrm{a}^{-1}$; Table 2).

Mid-season $R_{\mathrm{S}}$ rates in summer 2010 were similar across elevations at the core sites (cold sites: $4.4 \pm 0.1$; warm sites: $3.4 \pm 0.5$ ), and even higher at cold high-elevation sites than at warm low-elevation sites when the supplementary sites were included (cold sites: $4.4 \pm 0.1$; warm sites: $3.2 \pm 0.3 ; P=0.02$ ), and when daytime rates were averaged across measurement occasions and sites. This finding indicates that the elevational effect found for the year-round recordings at the core sites was not species specific. Mid-seasonal mean soil temperature was ca. $3 \mathrm{~K}$ higher at the warm sites than at the cold sites, and VWC varied between $30 \%$ and $37 \%$ and between $28 \%$ and $50 \%$ at the cold and the warm sites, respectively, during all measurements.

\section{Soil $\mathrm{C}$ and $\mathrm{N}$}

The amount of soil organic C $(0-50 \mathrm{~cm}$ depth $)$ was $15.3 \pm 0.3 \mathrm{~kg} \mathrm{C} \mathrm{m}^{-2}$ at the warm low-elevational sites and $4.8 \pm 2.2 \mathrm{~kg} \mathrm{C} \mathrm{m}^{-2}$ at the cold high-elevational sites. These values may not represent the total soil $\mathrm{C}$ stocks of the study sites, since soils can be much deeper. As both soil $\mathrm{C}$ and soil $\mathrm{N}$ concentrations were higher at the warm sites, 
Table 4 Soil properties along the soil profiles to a depth of $50 \mathrm{~cm}$ at the cold high-elevational and the warm low-elevational sites (mean $\pm \mathrm{SE} ; n=2$ )

\begin{tabular}{|c|c|c|}
\hline Soil depth & High elevation & Low elevation \\
\hline \multicolumn{3}{|l|}{$0-5 \mathrm{~cm}$} \\
\hline Bulk density $\left(\mathrm{g} \mathrm{cm}^{-3}\right)$ & $0.71 \pm 0.16$ & $0.96 \pm 0.09$ \\
\hline$\% \mathrm{C}$ & $3.27 \pm 0.35$ & $5.82 \pm 0.33$ \\
\hline $\mathrm{C}$ stock $\left(\mathrm{kg} \mathrm{C} \mathrm{m}^{-2}\right)$ & $1.18 \pm 0.38$ & $2.77 \pm 0.13$ \\
\hline $\mathrm{C} / \mathrm{N}$ & $11.18 \pm 1.59$ & $17.11 \pm 5.77$ \\
\hline $\mathrm{pH}_{(\mathrm{KCL})}$ & $5.25 \pm 0.01$ & $6.26 \pm 0.38$ \\
\hline \multicolumn{3}{|l|}{$5-10 \mathrm{~cm}$} \\
\hline Bulk density $\left(\mathrm{g} \mathrm{cm}^{-3}\right)$ & $1.15 \pm 0.01$ & $1.05 \pm 0.06$ \\
\hline$\% \mathrm{C}$ & $1.36 \pm 0.75$ & $3.33 \pm 0.15$ \\
\hline $\mathrm{C}$ stock $\left(\mathrm{kg} \mathrm{C} \mathrm{m}^{-2}\right)$ & $1.58 \pm 0.87$ & $3.50 \pm 0.05$ \\
\hline $\mathrm{C} / \mathrm{N}$ & $11.77 \pm 0.56$ & $9.86 \pm 0.42$ \\
\hline \multicolumn{3}{|l|}{$10-20 \mathrm{~cm}$} \\
\hline Bulk density $\left(\mathrm{g} \mathrm{cm}^{-3}\right)$ & $1.27 \pm 0.01$ & $1.10 \pm 0.01$ \\
\hline$\% \mathrm{C}$ & $0.28 \pm 0.05$ & $2.81 \pm 0.09$ \\
\hline $\mathrm{C}$ stock $\left(\mathrm{kg} \mathrm{C} \mathrm{m}^{-2}\right)$ & $0.35 \pm 0.09$ & $3.10 \pm 0.08$ \\
\hline $\mathrm{C} / \mathrm{N}$ & $12.72 \pm 2.45$ & $10.70 \pm 1.95$ \\
\hline \multicolumn{3}{|l|}{$20-30 \mathrm{~cm}$} \\
\hline Bulk density $\left(\mathrm{g} \mathrm{cm}^{-3}\right)$ & $1.22 \pm 0.09$ & $1.26 \pm 0.02$ \\
\hline$\% \mathrm{C}$ & $0.30 \pm 0.14$ & $1.95 \pm 0.24$ \\
\hline $\mathrm{C}$ stock $\left(\mathrm{kg} \mathrm{C} \mathrm{m}^{-2}\right)$ & $0.35 \pm 0.14$ & $2.44 \pm 0.26$ \\
\hline $\mathrm{C} / \mathrm{N}$ & $12.95 \pm 0.68$ & $9.03 \pm 0.31$ \\
\hline \multicolumn{3}{|l|}{$30-40 \mathrm{~cm}$} \\
\hline Bulk density $\left(\mathrm{g} \mathrm{cm}^{-3}\right)$ & $1.13 \pm 0.10$ & $1.20 \pm 0.06$ \\
\hline$\% \mathrm{C}$ & $0.77 \pm 0.55$ & $1.33 \pm 0.03$ \\
\hline $\mathrm{C}$ stock $\left(\mathrm{kg} \mathrm{C} \mathrm{m}^{-2}\right)$ & $0.77 \pm 0.50$ & $1.59 \pm 0.04$ \\
\hline $\mathrm{C} / \mathrm{N}$ & $11.53 \pm 1.23$ & $8.37 \pm 0.01$ \\
\hline \multicolumn{3}{|l|}{$40-50 \mathrm{~cm}$} \\
\hline Bulk density $\left(\mathrm{g} \mathrm{cm}^{-3}\right)$ & $1.16 \pm 0.12$ & $1.26 \pm 0.06$ \\
\hline$\% \mathrm{C}$ & $0.52 \pm 0.26$ & $1.54 \pm 0.44$ \\
\hline $\mathrm{C}$ stock $\left(\mathrm{kg} \mathrm{C} \mathrm{m}^{-2}\right)$ & $0.57 \pm 0.23$ & $1.91 \pm 0.46$ \\
\hline $\mathrm{C} / \mathrm{N}$ & $13.34 \pm 1.62$ & $10.46 \pm 1.05$ \\
\hline \multicolumn{3}{|l|}{$0-50 \mathrm{~cm}$ (total profile) } \\
\hline $\mathrm{C}$ stock $\left(\mathrm{kg} \mathrm{C} \mathrm{m}^{-2}\right)$ & $4.79 \pm 2.18$ & $15.32 \pm 0.27$ \\
\hline
\end{tabular}

the $\mathrm{C} / \mathrm{N}$ ratios were the same for both cold and warm sites along the sampled profile (Table 4).

\section{Discussion}

The temperature difference of about $6 \mathrm{~K}$ upon moving from alluvial cold study sites in the Swiss Central Alps to alluvial warm study sites in the foothills of the Swiss Plateau provided us with the opportunity to test effects of temperature as a driver of both forest productivity and forest $R_{\mathrm{s}}$. We found that neither annual $R_{\mathrm{s}}$ nor total annual litter production (i.e., the sum of the short-lived NPP components) depended significantly on elevation.

NPP components across the temperature cline

While total litter production hardly changed across elevations ( $+6 \%$, n.s.), canopy leaf litter vs. fine root litter showed contrasting components: more canopy litter $(+101 \%)$, but less fine root litter $(-71 \%)$ at the warm compared to the cold sites (Table 2).

Annual canopy leaf litter production at the cold $\left(117 \pm 22 \mathrm{~g} \mathrm{C} \mathrm{m}^{-2} \mathrm{a}^{-1}\right)$ and the warm $\left(235 \pm 27 \mathrm{~g} \mathrm{C} \mathrm{m}^{-2}\right.$ $\mathrm{a}^{-1}$; Table 2) sites compare well with the Swiss Forest Inventory data on canopy leaf litter input in the respective regions (Alps: $134 \mathrm{~g} \mathrm{C} \mathrm{m}^{-2} \mathrm{a}^{-1}$; Jura: $229 \mathrm{~g} \mathrm{C} \mathrm{m}^{-2} \mathrm{a}^{-1}$; Perruchoud et al. 1999). Further, the ten-year mean for the canopy leaf litter fall in the deciduous forest at the Swiss Canopy Crane research site located in the Jura foothills is almost identical to that observed at our warm low-elevation sites (238 $\pm 65 \mathrm{~g} \mathrm{C} \mathrm{m}^{-2} \mathrm{a}^{-1}$; Körner et al. 2005).

Annual understory litter production did not differ significantly between the cold and warm sites but, remarkably, was similar to canopy litter production at the cold sites, whereas understory litter production at the warm low-elevation sites was not even half of the canopy litter production (Table 2), most likely due to the greater shade produced by a closer canopy. However, we observed the reverse trend belowground to that seen for canopy litter production, with fine root production at the warm lowelevation sites reaching only one-third of that at the cold high-elevation sites (Table 2). To the extent that new root growth into an empty soil patch can be considered proportional to overall fine root production in such a site comparison, our cold sites showed a substantially higher root activity, perhaps associated with reduced microbial activity, scarcer nutrients, or a low temperature associated reduction in specific water uptake (Persson and Ahlström 1990). A similar increase in fine root production has been reported along elevational gradients in the Ecuadorian Andes (Roderstein et al. 2005, Moser et al. 2011), whereas a recent study along an elevational gradient in the Peruvian Andes found no such trend with elevation (Girardin et al. 2010). Fine root production in ingrowth cores at the warm sites was within the ranges previously reported for deciduous temperate forests based on the ingrowth core technique (Steele et al. 1997; Bader et al. 2009), whereas no literature data for a direct comparison with our cold highelevation sites was found. If we assume that the ratio of new roots appearing in ingrowth cores and the fine root stock is a proxy for root turnover, we arrive at rates that are slightly higher at the cold sites $\left(0.37 \mathrm{a}^{-1}\right)$ than at the warm sites $\left(0.31 \mathrm{a}^{-1}\right)$. The resultant root longevity of around three years is well within the range reported from other 
temperate deciduous forests (Bader et al. 2009, Gaul et al. 2009). The ratio of fine root ingrowth to total fine root biomass may overestimate actual turnover, since root growth into an empty soil patch may be greater than new root growth in undisturbed soil, but to a first approximation we can assume that such a deviation applies to all test sites, so it does not affect the comparison.

We did not develop species- and stand-specific allometries; nevertheless, our estimates of annual wood mass increment provide a rough estimate of the increase in wood $\mathrm{C}$ stocks. The annual wood increment of ca. $200 \mathrm{~g} \mathrm{C} \mathrm{m}^{-2}$ $\mathrm{a}^{-1}$ at our cold sites is close to the $170 \mathrm{~g} \mathrm{C} \mathrm{m}^{-2} \mathrm{a}^{-1}$ reported for a cold temperate forest in a similar climate in the northern USA (Gough et al. 2007), and the $485 \mathrm{~g} \mathrm{C}$ $\mathrm{m}^{-2} \mathrm{a}^{-1}$ observed at our warm sites falls in the range of 200-600 $\mathrm{g} \mathrm{C} \mathrm{m}^{-2} \mathrm{a}^{-1}$ found under similar climatic conditions in Germany, close to our warm sites (Jacob et al. 2010).

The effects of temperature on canopy leaf litter production and wood increment largely resulted from a longer growing season; the signals almost disappear when productivity is expressed per day available for growth (Table 3). The limitation on productivity caused by a shorter season (irrespective of temperature) is a global trend across latitudinal and elevational gradients covering the major vegetation types (Schulze 1982, Körner 1998). The higher annual root production at the cold sites became further amplified when expressed per day of the growing season (Table 3).

In summary, the productivity data obtained here are representative of similar forests elsewhere, and the elevational difference in annual rates of aboveground biomass production are largely explained by season length.

\section{Soil respiration at contrasting temperatures}

As in most previous cases, our data indicate that temperature controls the short-term temporal variability of $R_{\mathrm{s}}$ (Fig. 1), but the absolute rates of $R_{\mathrm{S}}$ are such that the elevational temperature effect on $R_{\mathrm{S}}$ is greatly diminished on an annual basis (Table 2).

Annual soil $\mathrm{C}$ efflux was similar at both elevations (cold sites: $836 \pm 5 \mathrm{~g} \mathrm{C} \mathrm{m}^{-2} \mathrm{a}^{-1}$; warm sites: $933 \pm 40 \mathrm{~g} \mathrm{C}$ $\mathrm{m}^{-2} \mathrm{a}^{-1}$ ), matching rates reported for other temperate deciduous forests (Malhi et al. 1999; Wang et al. 2006; Bader and Körner 2010; Ruehr et al. 2010), all of which corresponded to yearly soil $\mathrm{C}$ releases of between 700 and $1200 \mathrm{~g} \mathrm{C} \mathrm{m}^{-2} \mathrm{a}^{-1} . R_{\mathrm{s}}$ values for high-elevation deciduous forests that are comparable to those for our cold high-elevation sites do not exist, but cool temperate deciduous forests at a similar mean annual temperature were reported to release $700-800 \mathrm{~g} \mathrm{C} \mathrm{m}^{-2} \mathrm{a}^{-1}$ (compiled by Chen et al. 2011). Mid-season $R_{\mathrm{S}}$ rates at the supplementary sites indicate that our results are not species specific. We have nearly exhausted the spectrum of deciduous forest types at high elevation with Salix, Betula, and Sorbus. Abundant Alnus forests, also found at this elevation, cannot readily be compared due to their symbiotic $\mathrm{N}$ fixation and therefore higher nutrient availability (Caprez et al., unpublished).

Estimates of annual soil $\mathrm{C}$ release in climates subject to seasonal snow cover are often based on recordings taken during the growing season only. However, soil $\mathrm{C}$ release during winter can play a significant role in the annual $\mathrm{C}$ budget of seasonal forest ecosystems (Sommerfeld et al. 1993, Brooks et al. 2004), with soil temperatures of -7 to $-5{ }^{\circ} \mathrm{C}$ considered threshold temperatures for significant heterotrophic respiration (Brooks et al. 1997). At the cold sites of our study, below-snow soil temperatures were decoupled from air temperature by a thick snow pack, and never dropped below $0{ }^{\circ} \mathrm{C}$ (Fig. 1). Hence, our winter signals of $0.5 \mu \mathrm{mol} \mathrm{CO} \mathrm{CO}_{2} \mathrm{~m}^{-2} \mathrm{~s}^{-1}$ may be higher than what might generally apply for such elevations when the snowpack is shallower. Our estimates of $R_{\mathrm{s}}$ at high elevation in winter match those reported by Schindlbacher et al. (2007) for a forest ecosystem in the Austrian Alps (different method), while other studies that used open or closed chambers found lower (Mast et al. 1998), similar (McDowell et al. 2000), or higher (Mariko et al. 2000) belowsnow $R_{\mathrm{S}}$ rates than the rates recorded in our study. The four-month contribution of below-snow soil $\mathrm{CO}_{2}$ efflux to annual soil $\mathrm{CO}_{2}$ efflux at high elevation was about $16 \%$, a contribution similar to that reported for other temperate forest ecosystems (e.g., Schindlbacher et al. 2007: 12\%; Mariko et al. 2000: < $15 \%$; McDowell et al. 2000: $17 \%$ ).

Temperature and substrate relatedness of $R_{\mathrm{s}}$

The in situ relationships between $R_{\mathrm{s}}$ and soil temperature obtained here under steady state litter turnover indicate a downregulation of $R_{\mathrm{S}}$ at higher temperatures close to homeostasis; i.e., rates of $R_{\mathrm{S}}$ did not increase with increased seasonal mean temperature when moving across elevations (Fig. 2). Similar to our findings, EUROFLUX sites showed no correlation between annual $R_{\mathrm{s}}$ and mean annual temperature across a large range of European climates and tree species (Janssens et al. 2001). Further, a recent study across an elevational transect in tropical forests, spanning a larger temperature range than covered here, found no trend in $R_{\mathrm{S}}$ rates with elevation when daytime data were compared (Zimmermann et al. 2009), and only a weak positive relationship between $R_{\mathrm{S}}$ and temperature when night-time data were included (Zimmermann et al. 2010).

Responses of ecosystem respiration to temperature have often been described using the $Q_{10}$ concept, assuming that respiration more than doubles for warming of $10 \mathrm{~K}$ $\left(Q_{10}>2\right.$; Lloyd and Taylor 1994, Kirschbaum 1995). On a 
short-term basis (hours to days), we also found a $Q_{10}$ of close to 2 within both cold and warm sites (Fig. 2). However, the apparent $Q_{10}$ calculated across sites (e.g., moving from high to low elevations to simulate a $6 \mathrm{~K}$ warming) dropped to only $\sim 1.2$. This estimate is compatible with an apparent $Q_{10}$ of 1.4-1.5 across biomes differing in mean annual temperature (Mahecha et al. 2011; Bond-Lamberty and Thomson 2010). Thus, across biomes adapted to different temperatures, temperature does not exert a strong net influence on $R_{\mathrm{s}}$. Had annual $R_{\mathrm{s}}$ in the present study responded in a similar way to the short-term $Q_{10}$ of 2.15 (the mean of the $Q_{10}$ values at the cold and warm sites), a $6 \mathrm{~K}$ higher temperature should have caused a $65 \%$ increase in $R_{\mathrm{s}}$ relative to the substrate availability, which is not what we found. The proportionality to the short-lived NPP fraction (the amount of which also responds to temperature) when comparing cold and warm sites indicated that substrate availability rather than temperature controls annual $R_{\mathrm{s}}$.

A full accounting of all $\mathrm{C}$ input components and earmarking $\mathrm{C}$ output according to the contributions of these components is a near-to-impossible task (see the "Introduction"). This study aimed to quantify some major input pathways, use proxy measures for others, and leave the remaining inaccessible fractions (root exudates, $\mathrm{C}$ export to mycorrhiza) as residuals. Further, separating out belowground $\mathrm{C}$ release by auto- and heterotrophic fractions in a forest is a challenging task without performing severe experimental manipulation and therefore interfering with ecosystem functioning (e.g., Kuzyakov and Larionova 2005) and introducing unknown treatment bias. Such manipulations were beyond what could be done in this study.

In contrast to the linear relationship between annual $R_{\mathrm{s}}$ and annual canopy litter production as a single $\mathrm{C}$ input component, as reported by Raich and Nadelhoffer 1989, this study reveals that leaf litter input is insufficient to account for annual $R_{\mathrm{s}}$, which is not surprising. In a seasonal climate, canopy litter results from a single flush in spring, producing a site-specific LAI, with leaves shed at the same time in autumn. The seasonal $\mathrm{C}$ uptake by trees is then largely influenced by the leaf duration (i.e., the season length). In contrast, fine root production (and thus root turnover and associated release of organic $\mathrm{C}$ compounds) is likely to show a more continuous, more season length dependent $\mathrm{C}$ input to soils than canopy (leaf) litter production does. Since much of the belowground activity that induces respiratory $\mathrm{C}$ release is also related to aboveground biomass production, wood increment can be used to characterize the overall vigour of the system. However, due to the delayed respiratory recycling of wood, wood production in itself does not contribute directly to ongoing $R_{\mathrm{S}}$ on an annual basis as long as a forest grows.
We hypothesized that soil $\mathrm{C}$ output is largely controlled by available substrate ( $\mathrm{C}$ input), rather than by temperature per se, and that the relevant $\mathrm{C}$ input fractions on an annual basis are those undergoing continuous biomass recycling. If we take the often assumed ca. $50 \%$ autotrophic fraction of $R_{\mathrm{s}}$ (e.g., Bond-Lamberty et al. 2004; Hanson et al. 2000; Högberg et al. 2001) out of the roughly $900 \mathrm{~g}$ annual total respiratory $\mathrm{C}$ release from our soils, we arrive at ca. $400-500 \mathrm{~g}$ of $\mathrm{C}$ that should originate from the heterotrophic $\mathrm{CO}_{2}$ source, including unknown amounts of root exudates and mycorrhizal $\mathrm{C}$ consumption. Our estimates of total annual litter NPP explain $343 \mathrm{~g}(41 \%)$ and $365 \mathrm{~g}$ (39 \%) of the respiratory $\mathrm{C}$ release at the high- and lowelevation sites, respectively. Hence, ca. $10 \%$ of the assumed heterotrophic fraction of $R_{\mathrm{s}}$ remained unaccounted for, which is a reasonable estimate for root exudates and mycorrhizal consumption in temperate forests (15\% of NPP are reported by Vogt et al. 1982 for mature fir stands, 3-13\% of NPP are reported by Bekku et al. 1997 for temperate weed seedlings).

Hence, a similar quantity of $\mathrm{C}$ cycles through the soil within a year at both elevations, reinforcing our substratedependency hypothesis. Yet, in an undisturbed landscape, with all age classes of trees and forest parcels represented, including those where recalcitrant NPP (stems and branches) is at a recycling stage (decomposition of fallen logs), $\mathrm{CO}_{2}$ will be released that is not covered by our $R_{\mathrm{s}}$ values obtained in intact forest parcels. Clearly, the $6 \mathrm{~K}$ warmer annual temperatures did not significantly enhance soil $\mathrm{C}$ release on an annual basis, and instantaneous rates of $R_{\mathrm{s}}$ were downregulated, largely reflecting the annual input of labile C. Summing up, these results caution against expectations of strong positive effects of climatic warming on $R_{\mathrm{s}}$.

Finally, we assume that recent climatic warming was too slow to cause a significant deviation from a thermal equilibrium of metabolism (metabolism tracking temperature change) at our test sites. Thus, elevational gradients approximate the combined effects of temperature on all forest processes more closely then any experimental warming ever could. What natural thermal gradients cannot capture is long-term vegetation change, which will lag behind climatic change. The temperature dependency of $\mathrm{C}$ cycling across natural thermal gradients can assist in developing more realistic scenarios of $\mathrm{C}$ cycling in forests in a warmer climate than step changes in soil temperature only. We advocate whole-ecosystem approaches (i.e., the canopy and soils receive similar warming) and a wider appreciation and use of natural temperature contrasts in biological climate warming research.

Acknowledgments We are grateful to Franz Conen for soil C and N analysis, Eva Spehn for comments on the manuscrift draft, Erika 
Hiltbrunner for practical advice (all from the University of Basel), and to several volunteers for field assistance. Financial support was provided by COST-639 and the Swiss Federal Office for the Environment (BAFU)

\section{References}

Aber JD, Melillo JM, Nadelhoffer KJ, McClaugherty CA, Pastor J (1985) Fine root turnover in forest ecosystems to quantity and form of nitrogen availability: A comparison of two methods. Oecologia 66:317-321

Allison I, Bindoff NL, Bindoff RA et al (2009) The Copenhagen Diagnosis 2009: updating the world on the latest climate science. The University of New South Wales Climate Change Research Centre (CCRC), Sydney

Bader M, Hiltbrunner E, Körner C (2009) Fine root responses of mature deciduous forest trees to free air carbon dioxide enrichment (FACE). Functional Ecology 23:913-921

Bader MKF, Körner C (2010) No overall stimulation of soil respiration under mature deciduous forest trees after 7 years of $\mathrm{CO}_{2}$ enrichment. Global Change Biology 16:2830-2843

Bekku Y, Kimura M, Ikeda H, Koizumi H (1997) Carbon input from plant to soil through root exudation in Digitaria adscendens and Ambrosia artemisiifolia. Ecol Res 12:305-312

Bond-Lamberty B, Wang C, Gower ST (2004) A global relationship between the heterotrophic and autotrophic components of soil respiration? Global Change Biology 10:1756-1766

Bond-Lamberty B, Thomson A (2010) Temperature-associated increases in the global soil respiration record. Nature 464:579-582

Bradford MA, Davies CA, Frey SD et al (2008) Thermal adaption of soil microbial respiration to elevated temperature. Ecol Lett 11:1316-1327

Brooks PD, Schmidt SK, Williams MW (1997) Winter production of $\mathrm{CO}_{2}$ and $\mathrm{N}_{2} \mathrm{O}$ from alpine tundra: environmental controls and relationship to inter-system $\mathrm{C}$ and $\mathrm{N}$ fluxes. Oecologia 110:403-413

Brooks PD, McKnight D, Elder K (2004) Carbon limitation of soil respiration under winter snowpacks: potential feedbacks between growing season and winter carbon fluxes. Global Change Biology 11:231-238

Chen G, Yang Y, Guo J, Xie J, Yang Z (2011) Relationships between carbon allocation and partitioning of soil respiration across world mature forests. Plant Ecology 212:195-206

Conant RT, Ryan MG, Agren GI et al (2011) Temperature and soil organic matter decomposition rates-synthesis of current knowledge and a way forward. Global Change Biology 17:3392-3404

Cox PM, Betts RA, Jones CD, Spall SA, Totterdell IJ (2000) Acceleration of global warming due to carbon-cycle feedbacks in a coupled climate model. Nature 408:184-187

Cramer W, Bondeau A, Woodward FI et al (2001) Global response of terrestrial ecosystem structure and function to $\mathrm{CO}_{2}$ and climate change: results from six dynamic global vegetation models. Global Change Biology 7:357-373

Davidson EA, Belk E, Boone RD (1998) Soil water content and temperature as independent or confounded factors controlling soil respiration in a temperate mixed hardwood forest. Global Change Biology 4:217-227

Davidson EA, Savage K, Verchot LV, Navatto R (2002a) Minimizing artifacts and biases in chamber-based measurements of soil respiration. Agric For Meteorol 113:21-37

Davidson EA, Savage K, Bolstad P et al (2002b) Belowground carbon allocation in forests estimated from litterfall and IRGA-based soil respiration measurements. Agric For Meteorol 113:39-51
Davidson EA, Janssens IA (2006) Temperature sensitivity of soil carbon decomposition and feedbacks to climate change. Nature 440:165-173

Fischer H, Meyer A, Fischer K, Kuzyakov Y (2007) Carbohydrate and amino acid composition of dissolved organic matter leached from soils. Soil Biol Biochem 39:2926-2935

Friedlingstein P, Cox P, Betts R et al (2006) Climate-carbon cycle feedback analysis: results from the (CMIP)-M-4 model intercomparison. J Climate 19:3337-3353

Gaul D, Hertel D, Leuschner C (2009) Estimating fine root longevity in a temperate Norway spruce forest using three independent methods. Funct Plant Biol 36:11-19

Girardin CAJ, Malhi Y, Aragão LEOC et al (2010) Net primary productivity allocation and cycling of carbon along a tropical forest elevational transect in the Peruvian Andes. Global Change Biology 16:3176-3192

Gough CM, Vogel CS, Harrold KH, George K, Curtis PS (2007) The legacy of harvest and fire on ecosystem carbon storage in a north temperate forest. Global Change Biology 13:1935-1949

Hanson PJ, Edwards NT, Garten CT, Andrews JA (2000) Separating root and soil microbial contributions to soil respiration: a review of methods and observation. Biogeochemistry 48:115-146

Harris D, Horwath WR, Van Kessel C (2001) Acid fumigation of soils to remove carbonates prior to total organic carbon or carbon-13 isotopic analysis. Soil Sci Soc 65:1853-1856

Heath J, Ayres E, Possell M, Bardgett RD, Black HIJ, Grant H, Ineson $P$, Kerstiens G (2005) Rising atmospheric $\mathrm{CO}_{2}$ reduces sequestration of root-derived soil carbon. Science 309:1711-1713

Heimann M, Reichstein M (2008) Terrestrial ecosystem carbon dynamics and climate feedbacks. Nature 451:289-292

Högberg P, Nordgren A, Buchmann N, Taylor AFS, Ekblad A, Hogberg MN, Nyberg G, Ottoson Lofvenius M, Read DJ (2001) Large-scale forest girdling shows that current photosynthesis drives soil respiration. Nature 411:789-792

IPCC (2001) Climate Change 2001: impacts, adaptation and vulnerability. Cambridge University Press, Cambridge

IPCC (2007) Climate Change 2007: synthesis report. Cambridge University Press, Cambridge

Jacob M, Leuschner C, Thomas FM (2010) Productivity of temperate broad-leaved forest stands differing in tree species diversity. Ann For Sci 67:9

Janssens IA, Lankreijer H, Matteucci G et al (2001) Productivity overshadows temperature in determining soil and ecosystem respiration across European forests. Global Change Biology 7:269-278

Kirschbaum MUF (1995) The temperature dependence of soil organic matter decomposition, and the effect of global warming on soil organic C storage. Soil Biol Biochem 27:753-760

Knorr W, Prentice IC, House JI, Holland EA (2005) Long-term sensitivity of soil carbon turnover to warming. Nature 433:298-301

Körner C (1998) Alpine plants: stressed or adapted? In: Press MC, Scholes JD, Barker MG (eds) Physiological plant ecology. Blackwell, Oxford, pp 297-311

Körner C, Asshoff R, Bignucolo O et al (2005) Carbon flux and growth in mature deciduous forest trees exposed to elevated $\mathrm{CO}_{2}$. Science 309:1360-1362

Kuzyakov Y, Larionova AA (2005) Root and microbial respiration: a review of approaches to estimate respiration by autotrophic and heterotrophic organisms in soil. J Plant Nutr Soil Sci 168: 503-520

Kuzyakov Y, Gavrichkova O (2010) Time lag between photosynthesis and carbon dioxide efflux from soil: a review of mechanisms and controls. Global Change Biology 16:3386-3406

Leuschner C, Moser G, Bertsch C, Roderstein M, Hertel D (2007) Large altitudinal Increase in tree root/shoot ratio in tropical mountain forests of Equador. Basic Appl Ecol 8:219-230 
Lloyd J, Taylor JA (1994) On the temperature dependence of soil respiration. Funct Ecol 8:315-323

Lund CP, Riley WJ, Pierce LL, Field CB (1999) The effects of chamber pressurization on soil-surface $\mathrm{CO}_{2}$ efflux and the implications for NEE measurements under elevated $\mathrm{CO}_{2}$. Global Change Biology 5:269-281

Luo YQ, Wan SQ, Hui DF, Wallace LL (2001) Acclimatization of soil respiration to warming in a tall grass prarie. Nature 413:622-625

Mahecha MD, Reichstein M, Carvalhais N et al (2011) Global convergence in the temperature sensitivity of respiration at ecosystem level. Science 329:838-840

Malhi Y, Baldocchi DD, Jarvis PG (1999) The carbon balance of tropical, temperate and boreal forests. Plant Cell Environ 22:715-740

Mariko S, Nishimura N, Mo W, Matsui Y, Kibe T, Koizumi H (2000) Winter $\mathrm{CO}_{2}$ flux from soil and snow surfaces in a cool-temperate deciduous forest, Japan. Ecol Res 15:363-372

Mast MA, Wickland KP, Striegl RT, Clow DW (1998) Winter fluxes of $\mathrm{CO}_{2}$ and $\mathrm{CH}_{4}$ from subalpine soils in Rocky Mountain National Park, Colorado. Global Biogeochem Cy 12:607-620

McDowell NG, Marshall JD, Hooker TD, Musselman R (2000) Estimating $\mathrm{CO}_{2}$ flux from snowpacks at three sites in the Rocky Mountains. Tree Physiol 20:745-753

Melillo JM, Steudler PA, Aber JD et al (2002) Soil warming and carbon-cycle feedbacks to the climate system. Science 298:2173-2176

Moser G, Leuschner C, Hertel D, Graefe S, Soethe N, Iost S (2011) Elevation effects on the carbon budget of tropical mountain forests (S Ecuador): the role of the belowground compartment. Global Change Biology 17:2211-2226

Perruchoud D, Kienast F, Kaufmann E, Ulrich Bräker O (1999) 20th century carbon budget of forest soils in the Alps. Ecosystems 2:320-337

Persson H, Ahlström K (1990) The effects of forest liming on fertilization on fine-root growth. Water Air Soil Pollut 54:365375

R Development Core Team (2009) R: a language and environment for statistical computing. R Foundation for Statistical Computing, Vienna

Raich JW, Nadelhoffer KJ (1989) Belowground carbon allocation in forest ecosystems: global trends. Ecology 70:1346-1354

Raich JW, Schlesinger WH (1992) The global carbon-dioxide flux in soil respiration and its relationship to vegetation and climate. Tellus B 44:81-99

Raich JW, Potter CS (1995) Global patterns of carbon-dioxide emissions from soils. Global Biogeochem Cy 9:23-36
Roderstein M, Hertel D, Leuscher C (2005) Above- and belowground litter production in three tropical montane forests in southern Ecuador. J Trop Ecol 21:483-492

Ruehr N, Knohl A, Buchmann N (2010) Environmental variables controlling soil respiration on diurnal, seasonal and annual timescales in a mixed mountain forest in Switzerland. Biogeochemistry $98: 153-170$

Schindlbacher A, Zechmeister-Boltenstern S, Glatzel G, Jandl R (2007) Winter soil respiration from Austrian mountain forest. Agric For Meteorol 146:205-215

Schulze ED (1982) Plant life forms and their carbon, water and nutrient relations. Encycl Plant Physiol 12B:616-676

Schulze ED, Högberg P, van Oene H, Persson T, Harrison AF, Read D, Kjöller A, Matteucci G (2000) Interactions between the carbon and nitrogen cycle and the role of biodiversity: a synopsis of a study along a north-south transect through Europe. In: Schulze ED (ed) Carbon and nitrogen cycling in European forest ecosystems (Ecological Studies). Springer, Berlin, pp 468-491

Sommerfeld RA, Mosier AR, Musselman RC (1993) $\mathrm{CO}_{2}, \mathrm{CH}_{4}$ and $\mathrm{N}_{2} \mathrm{O}$ flux through a Wyoming snowpack and implications for global budgets. Nature 361:140-142

Steele SJ, Gower ST, Vogel JG, Norman JM (1997) Root mass, net primary production an turnover in aspen, jack pine and black spruce forests in Saskatchewan and Manitoba, Canada. Tree Physiol 17:577-587

Strömgren M, Linder S (2002) Effects of nutrition and soil warming on stemwood production in a boreal Norway spruce stand. Global Change Biology 8:1195-1204

Trumbore SE, Bonani G, Wölfi W (1990) The rates of carbon cycling in several soils from AMS ${ }^{14} \mathrm{C}$ measurements of fractionated soil organic matter. In: Bouwman AF (ed) Soils and the greenhouse effect. Wiley, New York, pp 405-414

Trumbore SE, Chadwick OA, Amundson R (1996) Rapid exchange between soil carbon and atmospheric carbon dioxide driven by temperature change. Science 272:393-396

Vogt KA, Grier CC, Meier CE, Edmonds RL (1982) Micorrhizal role in net primary production and nutrient cycling in Abies amabilis ecosystems in western Washington. Ecology 63:370-380

Wang C, Yang J, Zhang Q (2006) Soil respiration in six temperate forests in China. Global Change Biology 12:2103-2114

Zimmermann M, Meir P, Bird MI, Malhi Y, Ccahuana AJQ (2009) Climate dependence of heterotrophic soil respiration from a soiltranslocation experiment along a $3000 \mathrm{~m}$ tropical forest altitudinal gradient. Eur J Soil Sci 60:895-906

Zimmermann M, Meir P, Bird MI, Malhi Y, Ccahuana AJQ (2010) Temporal variation and climate dependence of soil respiration and its components along a $3000 \mathrm{~m}$ altitudinal tropical forest gradient. Global Biogeochem Cy 24:GB4012 